\title{
PHYTOTOXIC CONSTITUENTS FROM ENDOPHYTIC FUNGUS Xylaria cubensis ASSOCIATED WITH Eugenia brasiliensis
}

Carolina R. Biasetto ${ }^{a}$, Andressa Somensia, Viviane de C. P. Abdalla ${ }^{b}$, Lucas M. de Abreu ${ }^{c}$, Sonia C. J. Gualtieri ${ }^{\text {, }}$ Ludwig H. Pfenning ${ }^{\mathrm{d}}$, Vanderlan da S. Bolzani ${ }^{\mathrm{a}}$ and Angela R. Araujo ${ }^{\mathrm{a}, *,(\mathbb{C}}$

aDepartamento de Química Orgânica, Instituto de Química, Universidade Estadual Paulista, 14800-900 Araraquara - SP, Brasil bDepartamento de Botânica, Universidade Federal de São Carlos, 13565-905 São Carlos - SP, Brasil

'Departamento de Fitopatologia, Universidade Federal de Viçosa, 36570-000 Viçosa - MG, Brasil

${ }^{\mathrm{d}}$ Departamento de Fitopatologia, Universidade Federal de Lavras, 37200-000 Lavras - MG, Brasil

Recebido em 18/12/2018; aceito em 29/04/2019; publicado na web em 16/05/2019

\begin{abstract}
The upscaling of Xylaria cubensis, an endophyte of Eugenia brasiliensis (Myrtaceae), in PDB medium led to the isolation of known compounds including cytochalasin D (7) and cytochalasin C (8), which exhibited relatively higher phytotoxic activity in all the concentrations tested compared to the commercial herbicide $\mathrm{GOAL}^{\oplus}$. Besides the aforementioned metabolites, one diketopiperazine (DKP) and two isocoumarins were isolated and two DKPs were also identified in the mixture. The structures were determined by 1D and $2 \mathrm{D}{ }^{1} \mathrm{H}$ NMR, MS analyses and were compared with the literature.
\end{abstract}

Keywords: endophytic fungi; Xylaria cubensis; cytochalasins; phytotoxic activity.

\section{INTRODUCTION}

The discovery of natural products from the microbial universe has much to be explored ${ }^{1}$ and within this context endophytic fungi are being seen as the new source of bioactive substances. ${ }^{2}$ Endophytic fungi have the capacity to produce a wide variety of enzymes and secondary metabolites, which exhibit various biological activities. ${ }^{3}$ Currently, microorganisms are one of the most important life forms, which provides biotechnological tools for the transformation of organic matter, as well as the production of useful chemicals and biochemicals. ${ }^{4}$

The search for new phytotoxic compounds is the most importance for humanity, since, more and more plantations are harmed by weeds, reducing the availability of food for the populations. To combat them, synthetic herbicides are used in large quantities, which cause environmental and ecological impacts. In this context the sustainable control of weeds by bioherbicides is necessary. Although all efforts to obtain bioherbicides derived from natural sources, only thirteen are available in the market. ${ }^{5}$ The search for new bioherbicides, coupled with data from the literature, shows that natural products such as cytochalasins isolated from endophytic fungi present phytotoxic activity, and these become a promising source to explore new metabolites for the control of weeds offering food and environmental safety.

Eugenia brasiliensis (Myrtaceae), known in Brazil as "grumixama" or Brazilian cherry, grows on the coast of the Brazilian forests and it is known to be endowed with antioxidant and anti-inflammatory capacity. ${ }^{6,7}$ This plant species exhibits a wide range of endophytes, among them Xylaria cubensis which was selected for chemical and biological investigations due its phytotoxic, antifungal and anticholinesterasic activities. Chemical investigations of the $X$. cubensis revealed new natural products as sesquiterpenoids, diterpenoids, aliphatic derivative and isocoumarin. ${ }^{8}$ Sawadsitang et al. ${ }^{9}$ reported that Xylaria cf. cubensis produced cytochalasin D, tryptoquivaline L, fiscalin C, epi-fiscalin C, ergosterol, ergosterol peroxide, chevalone $\mathrm{C}$, xylaranol $\mathrm{B}$ and helvolic

*e-mail: angela.araujo@unesp.br acid. Among these substances the cytochalasin D and ergosterol peroxide highlighted by highly cytotoxicity against NCI-H187 cancer cell line. In addition, the substances chevalone $\mathrm{C}$ and helvolic acid showed antimalarial activity. ${ }^{9}$

The isolated cytochalasins D and C in this work presented a pronounced phytotoxic potential relative to the inhibition of wheat coleoptiles growth, regarded an important activity when it comes to combating weeds. The high yield of the cytochalasins produced by $X$. cubensis and its already described phytotoxicity motivated its study.

\section{EXPERIMENTAL}

\section{General information}

The NMR spectra were recorded on a Bruker 300 Fourier $(7,1 \mathrm{~T})$ and a Bruker Avance III HD 600 (14,1 T) spectrometer using the nondeuterated residual signal (DMSO and $\mathrm{CD}_{3} \mathrm{OD}$ ) as reference. Mass spectra of high resolution were obtained on a spectrometer Bruker Maxis Impact-ESI-QqTOF-MS. The mass spectra of low resolution were obtained on a spectrometer Thermo Scientific LCQ Fleet Ion Trap with electrospray ionization source (ESI). Optical rotation values were measured on a Perkin-Elmer polarimeter, model 241, at the sodium D line $(\lambda=589 \mathrm{~nm})$. TLC analyses were performed using Macherey-Nagel gel 60 G F254. Spots on TLC plates were visualized under UV light and by spraying with anisaldehyde $-\mathrm{H}_{2} \mathrm{SO}_{4}$ reagent followed by heating at $120^{\circ} \mathrm{C}$. Columns chromatographies (CC) were performed over reversed-phase silica gel 50-60 mesh (MachereyNagel). Analytical HPLC was performed on a Shimadzu (Shimadzu SPD-M20A) with diode array ultraviolet (DAD) detector, using a Phenomenex Gemini (C-18) (250 x $4.60 \mathrm{~mm}, 5 \mathrm{mM})$ analytical column. Preparative HPLC was performed on Shimadzu (Shimadzu SPD-M20A), using a Phenomenex Luna C-18 silica (250 x 10.0 mm; $5 \mu \mathrm{m})$ semi-preparative column.

\section{Fungal isolation and identification}

The endophytic fungus Xylaria cubensis was isolated from healthy branches of Eugenia brasiliensis, which were subjected to surface 
sterilization. The branches were first washed with running water and then immersed in a $1 \%$ aqueous sodium hypochlorite solution for $5 \mathrm{~min}$ and subsequently in $70 \%$ aqueous $\mathrm{EtOH}$ for $3 \mathrm{~min}$. Thereafter, the branches were immersed in sterile $\mathrm{H}_{2} \mathrm{O}$ for $15 \mathrm{~min}$. The sterilized branches were cut into $2 \times 2 \mathrm{~cm}$ pieces and deposited approximately 3 to 4 pieces in each Petri dish containing PDA (potato-dextrose agar) and gentamicin sulfate antibiotic $\left(66,7 \mu \mathrm{g} \mathrm{mL}^{-1}\right)$ to inhibit the growth of endophytic bacteria. The material was incubated at $25{ }^{\circ} \mathrm{C}$ for 10 days and the endophyte Xylaria cubensis was isolated by successive replication and preserved in sterile water. ${ }^{10}$ Eugenia brasiliensis was collected in the Horto of the School of Pharmaceutical Sciences, São Paulo State University - Araraquara-UNESP, Brazil, in May 2012 ( $21^{\circ} 48^{\prime} 52,44 \mathrm{~S} 48^{\circ} 12^{\prime} 7,13 \mathrm{~W}$ ). The fungus was identified by Dr. Ludwig H. Pfenning using alpha-actin gene and deposited in the GenBank database under the access number KY006658.

\section{Cultivation and isolation of metabolites}

The endophytic fungus Xylaria cubensis was cultivated in seventeen Erlenmeyer flasks $(500 \mathrm{~mL})$ each containing $0.8 \mathrm{~g}$ of potato starch, $4.0 \mathrm{~g}$ dextrose (PDB) and $300 \mathrm{~mL}$ distilled water, which were autoclaved at $121{ }^{\circ} \mathrm{C}$ for $20 \mathrm{~min}$. Following sterilization, the culture media were inoculated with the endophyte and incubated in static mode at $25^{\circ} \mathrm{C}$ for 28 days. After the period of incubation, the fermentation broth was separated from the mycelium by vacuum filtration and subjected to liquid-liquid partition with EtOAc $(3 \times 2.5 \mathrm{~L})$. The solvent was evaporated, yielding a crude EtOAc extract $(641.3 \mathrm{mg})$.

This crude extract was fractioned by column chromatography (CC) using reversed phase silica gel and eluted with a $\mathrm{H}_{2} \mathrm{O}: \mathrm{CH}_{3} \mathrm{OH}$ gradient (30-100\% $\left.\mathrm{CH}_{3} \mathrm{OH}(\mathrm{v} / \mathrm{v})\right)$ resulting in six fractions ( $\left.\mathrm{Fr} 1-\mathrm{Fr} 6\right)$. Fraction Fr1 $(290 \mathrm{mg})$ was further fractioned using $80 \mathrm{mg}$ of the sample, reversed phase and semi-preparative HPLC $[\lambda=220$ and $254 \mathrm{~nm}, 4.0 \mathrm{~mL} \mathrm{~min}{ }^{-1}, \mathrm{H}_{2} \mathrm{O}: \mathrm{CH}_{3} \mathrm{OH}$ gradient (95:05-25:75-0:10095:05 v/v)], leading to fractions $\mathbf{1}(1.3 \mathrm{mg}), \mathbf{2}(2.9 \mathrm{mg}), \mathbf{3}$ and $\mathbf{4}(3.1$ $\mathrm{mg}$ ). Fraction Fr2 (200.1 mg) was further fractioned using $80 \mathrm{mg}$ of sample, reversed phase and prep. HPLC $\left[\lambda=254 \mathrm{~nm}, 10.0 \mathrm{~mL} \mathrm{~min}^{-1}\right.$, $\mathrm{H}_{2} \mathrm{O}: \mathrm{CH}_{3} \mathrm{OH}$ gradient (70:30-28:72-0:100-70:30 v/v)], yielding fractions 5 (3.5 mg), 6 (1.0 mg) and 7 (24.0 mg). Fr3 (80.0 mg) was further fractioned using reversed phase and semiprep. HPLC $[\lambda=220$

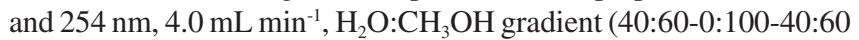
$\mathrm{v} / \mathrm{v})$ ], yielding fractions $7(1.7 \mathrm{mg})$ and $\mathbf{8}(3.5 \mathrm{mg})$.

\section{Cyclo(L-Pro-L-Tyr) (2)}

Yellow powder. $[\alpha]_{\mathrm{D}}{ }^{37}-20\left(\mathrm{c} 0.3, \mathrm{CH}_{3} \mathrm{OH}\right), \mathrm{UV}\left(\mathrm{CH}_{3} \mathrm{OH}\right)$ $\lambda_{\max } 274 \mathrm{~nm}$. The ${ }^{1} \mathrm{H}$ and ${ }^{13} \mathrm{C}$ NMR spectroscopic data were found to be consistent with those reported in the literature. ${ }^{11}$

\section{(-)-5-carboxy-6-hydroxy-3-methyl-3,4-dihydroisocumarin (5)}

Yellow powder. $[\alpha]_{\mathrm{D}}{ }^{38}-44\left(\mathrm{c} 0.03, \mathrm{CH}_{3} \mathrm{OH}\right)$. UV $\left(\mathrm{CH}_{3} \mathrm{OH}\right)$

$\lambda_{\max } 249,342$. The ${ }^{1} \mathrm{H}$ and ${ }^{13} \mathrm{C}$ NMR spectroscopic data were found to be consistent with those reported in the literature..$^{12,13}$

\section{(R)-7-hydroxymelein (6)}

Yellow powder. $[\alpha]_{\mathrm{D}}{ }^{37}-25$ (c $\left.0.06, \mathrm{CHCl}_{3}\right)$. UV $\left(\mathrm{CH}_{3} \mathrm{OH}\right)$ $\lambda_{\max } 224,309$. The ${ }^{1} \mathrm{H}$ and ${ }^{13} \mathrm{C}$ NMR spectroscopic data were found to be consistent with those reported in the literature. ${ }^{13}$

\section{Cytochalasin D (7)}

White crystal. $[\alpha]_{D}{ }^{39}+26\left(\right.$ c $\left.0.25, \mathrm{CH}_{3} \mathrm{CH}_{2} \mathrm{OH}\right)$. UV $\left(\mathrm{CH}_{3} \mathrm{OH}\right)$ $\lambda_{\max } 284 \mathrm{~nm}$. The ${ }^{1} \mathrm{H}$ and ${ }^{13} \mathrm{C}$ NMR spectroscopic data were found to be consistent with those reported in the literature. ${ }^{14}$ HRESIMS $m / z 508.2742\left([\mathrm{M}+\mathrm{H}]^{+}, \mathrm{C}_{30} \mathrm{H}_{37} \mathrm{O}_{6} \mathrm{~N}\right)$.

\section{Cytochalasin C (8)}

Yellow powder $[\alpha]_{\mathrm{D}}{ }^{38}-8\left(\mathrm{c} 0.25, \mathrm{CH}_{3} \mathrm{CH}_{2} \mathrm{OH}\right)$. UV $\left(\mathrm{CH}_{3} \mathrm{OH}\right)$ $\lambda_{\max } 282 \mathrm{~nm}$. The ${ }^{1} \mathrm{H}$ and ${ }^{13} \mathrm{C}$ NMR spectroscopic data were found to be consistent with those reported in the literature. ${ }^{15}$ HRESIMS $\mathrm{m} / \mathrm{z} 508.2682\left([\mathrm{M}+\mathrm{H}]^{+}, \mathrm{C}_{30} \mathrm{H}_{37} \mathrm{O}_{6} \mathrm{~N}\right)$.

\section{Phytotoxic activity on wheat coleoptiles (Triticum aestivum $\mathbf{L}$.)}

Phytotoxic activity was assessed in compounds $\mathbf{7}$ and $\mathbf{8}$ using wheat coleoptile bioassay (Triticuma estivum L. variety Pizon). The other substances isolated in this work did not present sufficient mass for the biological tests. First, wheat caryopses were germinated in distilled water and kept in a growth chamber at $25^{\circ} \mathrm{C}$ for 4 days in the absence of light, as described by Hancock et al. ${ }^{16}$ Subsequently, coleoptiles were selected and cut with a Van der Weij guillotine under green light to avoid the stagnation of cell growth..$^{17,18}$ The apices of the coleoptiles were discarded, while the next $4 \mathrm{~mm}$ was cut and placed in test tubes containing a buffer solution ( $\mathrm{pH}$ 5.6) composed of sucrose $\left(20 \mathrm{~g} \mathrm{~L}^{-1}\right)$, citric acid monohydrate $\left(1.05 \mathrm{~g} \mathrm{~L}^{-1}\right)$ and dipotassium hydrogen $(2.9 \mathrm{v}) .{ }^{17} 2 \mathrm{~mL}$ of the test solutions in DMSO at concentrations of $0.8,0.4$ and $0.2 \mathrm{mg} \mathrm{mL}^{-1}$ and five coleoptiles were added to each tube. The commercial herbicide GOAL ${ }^{\circledR}$ (Oxyfluorfen, 240 g.i.a L ${ }^{-1}$ ) was used as positive control at the same concentrations of the fractions while the buffer solution with DMSO was employed as negative control. These tubes were randomly divided and maintained at $25{ }^{\circ} \mathrm{C}$ in the dark under a constant rotation of $6 \mathrm{rpm}$, with three replicates per treatment. ${ }^{17}$ After 24 hours, the coleoptiles were removed from the tubes, photographed and measured with the aid of image scanning software (Image J.). Data were evaluated by the percentage of inhibition or stimulation compared to the negative control, where $0 \%$ denotes the control length, while positive values imply growth stimulation and negative values imply inhibition. ${ }^{19}$ Statistical analyses: All the results were tested for normality and homogeneity using the Shapiro-Wilk and Levene tests, respectively. Normal homogeneous data were analyzed by ANOVA, followed by Tukey test $(\mathrm{p}<0.05)$ using PAST version 2.5.

\section{RESULTS AND DISCUSSIONS}

The compounds (1-8) (Figure 1) were obtained from the EtOAc extract. It should be noted that these compounds were not detected in PDB medium in the absence of the fungus (X. cubensis). The spectral data (MS, ${ }^{1} \mathrm{H}$ and ${ }^{13} \mathrm{C}$ NMR spectra) of compounds $\mathbf{1 - 8}$ were found to be identical to those reported in the literature. ${ }^{6-9,11,13-15,20}$ The structures were identified as adenosine (1), cyclo(L-Pro-L-Tyr) (2), 5-carboxy-6-hydroxy-3-methyl-3,4-dihydroisocoumarin (5), 7-hydroxymelein (6), cytochalasin D (7) and cytochalasin C (8). In addition, two DKPs cyclo(Pro-Val) (3) and cyclo(Val-Tyr) (4) were also identified in the mixture. ${ }^{11,13-15,20,21}$ Adenosine (1) did not only exhibit potential DPPH-scavenging activities but was also found to stimulate seed germination of Raphanus sativus, Brassica napus and $B$. chinensis. ${ }^{22,23}$ The compound $\mathbf{2}$ has been reported to exhibit allelopathic and antibacterial activity apart from its ecological significance. ${ }^{24}$ The DKPs are known to possess important biological activities including antiviral, antimicrobial, antitumor and allelopathic activities. ${ }^{25-27}$ The isocoumarins are likewise found to possess antioxidant, antiallergic, antimalarial, and cytotoxic activities. They also exhibit bioactive potential against phytopathogenic fungi and are used as drug prototypes for the treatment of Alzheimer's disease. ${ }^{13,28,29}$

\section{Phytotoxic Activity}

The cytochalasin D (7) and cytochalasin C (8) significantly inhibited wheat coleoptile growth at all the concentrations investigated 
<smiles>Nc1ncnc2c1ncn2[C@@H]1O[C@H](CO)[C@@H](O)[C@H]1O</smiles>

(1)<smiles>CC(C)[C@H]1NC(=O)[C@H](Cc2ccc(O)cc2)NC1=O</smiles>

(4)<smiles>O=C1N[C@H](Cc2ccc(O)cc2)C(=O)N2CCC[C@H]12</smiles>

(2)<smiles>C[C@H]1Cc2c(ccc(O)c2C(=O)O)C(=O)O1</smiles>

(5)<smiles>CC(C)[C@@H]1NC(=O)[C@@H]2CCCN2C1=O</smiles>

(3)

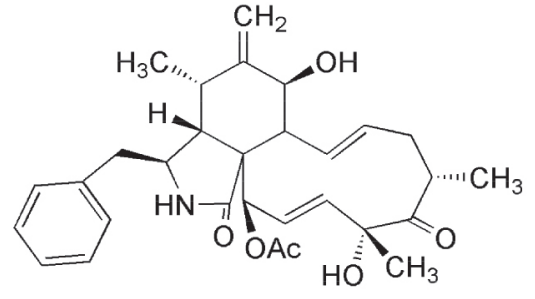

(7)

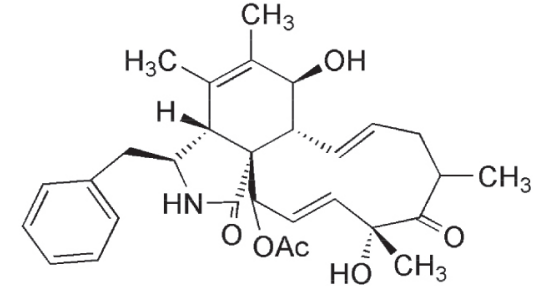

(8)

Figure 1. Structures of compounds 1-8 produced by X. cubensis.

(Figures $1 \mathrm{~S}$ and $2 \mathrm{~S}$ ) compared to the negative control. The inhibition percentages of the compounds $\mathbf{7}$ and $\mathbf{8}$ were found to be higher compared to that of the commercial herbicide GOAL ${ }^{\circledR}$ (Oxyfluorfen $240 \mathrm{~g} \mathrm{~mL}^{-1}$ ) at all the concentrations tested. Tables S1 and S2 show average coleoptile growth under the effect of compounds $\mathbf{7}$ and $\mathbf{8}$ and the average coleoptile growth of the positive control $\left(\mathrm{GOAL}^{\circledR}\right)$ at the same concentrations. The average coleoptile growth for compounds 7 $\left[10^{-3} \mathrm{~mol} \mathrm{~L}^{-1}\right]$ and $8\left[3.10^{-4} \mathrm{~mol} \mathrm{~L}^{-1}\right]$ and $\left[10^{-4} \mathrm{~mol} \mathrm{~L}^{-1}\right]$ and $\mathrm{GOAL}^{\circledR}$ herbicide did not differ statistically.

This study confirms the phytotoxic potential of compounds $\mathbf{7}$ and 8 in wheat coleoptile elongation and their relevant usefulness in the control of weeds. Indeed, these results unfold possibilities for further studies. It is worth pointing out that the production of cytochalasin $\mathrm{D}$, a bioherbicide potential, using $X$. cubensis was constituted by approximately $10 \%$ of crude extract in this study. Other studies reported in the literature have demonstrated that cytochalasin D presents relevant biological activities including antibiotic, antitumor, antifungal and phytotoxic activities. ${ }^{28}$

\section{CONCLUSION}

The present work has demonstrated that $X$. cubensis is an excellent producer of secondary metabolites derived from various biosynthetic pathways. This fungus produced isocoumarins, DKPs and cytochalasins, which are associated with numerous important biological activities. Clearly, further studies need to be conducted so as to confirm the phytotoxic activity of cytochalasins D and C. While synthetic herbicides have a high degree of toxicity to the environment and low degradation rates, contributing towards altering natural ecosystems, these metabolites could be positively exploited as future bioherbicides for the control of weeds offering environmental safety.

\section{SUPPLEMENTARY MATERIAL}

Tables $1 \mathrm{~S}$ and $2 \mathrm{~S}$ and Figures $1 \mathrm{~S}$ and $2 \mathrm{~S}$ and other data are available online.

\section{ACKNOWLEDGMENTS}

The authors would like to express their sincerest gratitude and indebtedness to the Brazilian Research Funding Agencies - CNPq, grant no. 140980/2012-1 and FAPESP as part of CEPID/CIBFar, grant no. 2013/07600-3. CRB expresses her gratitude to the CNPq for PhD's scholarship granted.

\section{REFERENCES}

1. Cragg, G. M.; Grothaus, P. G.; Newman, D.; J. Chemical Rev. 2009, 109, 3043.

2. Strobel, G. A.; Daisy, B.; Microbiol. Mol. Biol. Rev. 2003, 67, 502.

3. Corrêa, R. C. G.; Rhoden, S. A.; Mota, T. R.; Azevedo, J. L.; Pamphile, J. A.; Souza, C. G. M.; Polizeli, M. L. T. M.; Bracht, A.; Peralta, R. M.; J. Ind. Microbiol. Biotechnol. 2014, 41, 1478.

4. Ióca, L. P.; Allard, P. M.; Berlinck, R. G. S.; Nat. Prod. Rep. 2014, 31, 675 .

5. Cordeau, S.; Triolet, M.; Wayman, S.; Steinberg, C.; Guillemin, J. P.; Crop Prot. 2016, 87, 49.

6. Fischer, D. C. H.; Limberger R. P.; Henriques A. T.; Moreno P. R. H.; J. Essent. Oil Res. 2005, 17, 500.

7. Teixeira, L. L.; Bertoldi, F. C.; Lajolo, F. M.; Hassimotto N. M. A.; J. Agric. Food Chem. 2015, 63, 5427.

8. Fan, N. W.; Chang, H. S.; Cheng, M. J.; Hsieh, S. Y.; Liu, T. W.; Yuan, G. F.; Chen, I. S.; Helv. Chim. Acta 2014, 97, 1699. 
9. Sawadsitang, S.; Mongkolthanaruk, W.; Suwannasai, N.; Sodngam, S.; Nat. Prod. Lett. 2015, 29, 2036.

10. Teles, H. L.; Sordi, R.; Silva, G. H.; Gamboa, I. C.; Bolzani, V. S.; Pfenning, L. H.; Abreu, L. M.; Neto, C. M. C.; Young, M. C. M.; Araujo, A. R.; Phytochemistry 2006, 67, 2690.

11. Jayatilake, G. S.; Thornton, M. P.; Leonard, A. C.; Grimwade, J. E.; Baker, B. J.; J. Nat. Prod. 1996, 59, 296.

12. Anderson, J. R.; Edwards, R. L.; Whalley, A. J. S.; J. Chem. Soc. Perkin Trans. I 1983, 2192.

13. Oliveira, C. M.; Regasini, L. O.; Silva, G. H.; Pfenning, L. H.; Young, M. C. M.; Berlinck, R. G. S.; Bolzani, V. S.; Araujo, A. R.; Phytochemistry Lett. 2011, 4, 96.

14. Cafêu, M. C.; Silva, G. H.; Teles, H. L.; Bolzani, V. S.; Araujo, A. R.; Young, M. C. M.; Pfenning, L. H.; Quim. Nova 2005, 28, 995.

15. Cole, R. J.; Jarvis, B. B.; Schweikert, M. A.; In Handbook of Secondary Fungal Metabolites, Academic Press: San Diego, California. 2003.

16. Hancock, C. R.; Barlow, H.W.; Lacey, H. J.; J. Exp. Bot. 1964, 15, 176.

17. Macías, F. A.; Lacret, R.; Varela, R. M.; Nogueiras, C.; Molinillo, J. M. G.; J. Chem. Ecol. 2010, 36, 404.

18. Nitsch, J. P.; Nitsch, C.; Plant Physiol. 1956, 31, 111.

19. Novaes, P.; Imatomi, M.; Varela, R. M.; Molinillo, J. M.; Lacret, R.; Gualtieri, S. C.; Macías, F. A.; Chemistry \& Biodiversity 2013, 10, 1548.
20. Domondon, D. L.; He, W.; Kimpe, N.; Höfte, M.; Poppe, J.; Phytochemistry 2004, 65, 187.

21. Stark, T.; Hofmann, T.; J. Agric. Food Chem. 2005, 53, 7231.

22. Ma, Y. T.; Qiao, L. R.; Shi, W. Q.; Zhang, A. L.; Gao, J. M.; Chem. Nat. Compd. 2010, 46, 506.

23. Yuan, Y.; Tian, J. M.; Xiao, J.; Shao, Q.; Gao, J. M.; Nat. Prod. Res. 2014, 28, 281.

24. Wang, L.; Zheng, C. D.; Li, X. J.; Gao, J. M.; Zhang, X. C.; Wei, G. H.; Chem. Nat. Compd. 2011, 47, 1042.

25. Martins, M. B.; Carvalho, I.; Tetrahedron 2007, 63, 9932.

26. Gendy, B. D. M.; Rateb, M. E.; Bioorg. Med. Chem. Lett. 2015, 25, 3128 .

27. Zhang, Q.; Wang, S. Q.; Tang, H. Y.; Li, X. J.; Zhang, L.; Xiao, J.; Gao, Y. Q.; Zhang, A. L.; Gao, J. M.; J. Agric. Food Chem. 2013, 61, 11452.

28. Araujo, A. R.; Chapla, V. M.; Biasetto, C. R.; Zeraik, M.L.; Em Produtos Naturais Bioativos; Santos, L. C.; Furlan, M.; Amorim, M. R., eds.; Cultura Acadêmica: São Paulo, 2016, cap. 7.

29. Simic, M.; Paunovic, N.; Boric, I.; Randjelovic, J.; Vojnovic, S.; Runic, J. N.; Pekmezovic, M.; Savic, V.; Bioorg. Med. Chem. Lett. 2016, 26 , 239. 